\title{
SERGANČIŲJŲ COVID - 19 LIGA PLAUČIŲ ULTRAGARSINIO TYRIMO VERTINIMO ASPEKTAI IR KLINIKINĖ NAUDA
}

\author{
Vilma Galdikaitė, Monika Pinchasov \\ Lietuvos sveikatos mokslu universitetas
}

\section{Raktažodžiai}

COVID-19, SARS-CoV-2, koronavirusas, ultragarsas, sonografija, plaučiai, krūtinè.

\begin{abstract}
Santrauka
Plaučių ultragarsinis tyrimas COVID-19 pandemijos aplinkoje parodè didelę klinikinę vertę diagnozuoti plaučių pažeidimo lygi šios ligos metu. Tyrimo tikslas - apžvelgti prieinamą mokslinę literatūrą apie pagrindinius plaučių ultragarso vertinimo aspektus ir metodus, padèsiančius ištirti bei numatyti galimas sergančiujjų COVID - 19 ligos baigtis, priklausomas nuo plaučiu pažeidimo būklès. Literatūros šaltinių paieška atlikta kompiuterinèse bibliografinèse mokslinių darbų bazèse PubMed, Google Scholar, ScienceDirect, naudojant raktinius žodžius ir jų derinius: COVID-19, SARS-CoV-2, koronavirusas, ultragarsas, sonografija, plaučiai, krūtinè. I sisteminę apžvalgą itraukti 2015-2020 m. moksliniai straipsniai ir tyrimai anglų kalba. Tyrimo rezultatai parodè, kad sveikų plaučių ultragarsiniame tyrime matomos A linijos, rodančius sveikus oringus plaučius. Progresuojant COVID ligai, atsiranda B1 linijos, rodančios intersticinio audinio sustorejjimą ir uždegimo apimtą plaučių audinį. Sunkesniais ligos atvejais B linijos susilieja, dideja jų skaičius, ryškejja vadinamieji „balti plaučiai“ (B2 linijos). Esant sunkiai ligos formai, atsiranda vadinamosios konsolidacijos zonos. Vertinant šiuos požymius 6 skirtinguose segmentuose, galima apskaičiuoti ultragarsinio tyrimo balą, kuris naudingas vertinti plaučių pažeidimą dinamikoje, - kuo skaičius didesnis, tuo mažesnis plaučių oringumas ir atvirkščiai. Plaučiu ultragarso privalumas tas, kad tyrimas gali būti atliekamas taip dažnai, kaip reikia, nes nèra toks kenksmingas pacientui, kaip rentgenologinis ar kompiuterinès tomografijos tyrimas dèl savo spinduliuotès. Išvados. Ultragarsinis tyrimas yra naudingas diagnostikos metodas apibūdinti COVID-19 liga sergančių pacientų plaučių pažeidimo lygị, kuris nustatomas vertinant dinamikoje atsirandančias A, B1, B2, C struktūras.
\end{abstract}

Ivadas

COVID -19 pandemija sukèlè beprecendentị spaudimą sveikatos priežiūros sistemai ir jos grandims dèl ypač sunkios būklès pacientų priežiūros ir gydymo [1].

Daug informacijos apie koronaviruso liga sergančių pacientų būklę, kvẻpavimo nepakankamumo sunkumą, plaučių pažeidimo lygi gali suteikti plaučių ir gretimų audinių ultragarsinis tyrimas, reikalingas priimti klinikinius sprendimus, susijusius su šių pacientų gydymo taktika. Šis tyrimo metodas gali pasitarnauti COVID - 19 liga sergančių pacientų ligos progresavimo ar pasveikimo vertinimui [3]. Jau žinomus plaučiu ultragarso vertinimo principus ir metodiką galima taikyti pacientams, sergantiems COVID - 19 liga [4], tačiau yra ir daugiau įrodymų, patvirtinančių plaučių ultragarso klinikinę vertę [2].

Tyrimo tikslas - apžvelgti prieinamą mokslinę literatūrą apie pagrindinius plaučių ultragarso vertinimo aspektus ir metodus, padèsiančius ištirti bei numatyti galimas sergančiųų COVID - 19 ligos baigtis, priklausomas nuo plaučių pažeidimo būklès.

\section{Tyrimo medžiaga ir metodai}

Literatūros šaltinių paieška atlikta kompiuterinèse bibliografinèse mokslinių darbų bazèse PubMed, Google Scholar, ScienceDirect, naudojant raktinius žodžius ir jų derinius: COVID-19, SARS-CoV-2, koronavirusas, ultragarsas, sonografija, plaučiai, krūtinè. İ sisteminę apžvalgą įtraukti 2015-2020 m. moksliniai straipsniai ir tyrimai anglų kalba.

\section{Tyrimo rezultatai ir jų aptarimas}

Progresuojant COVID 19 ligai, pakitimai plaučiu parenchimoje prasideda tolimesnèse plaučių dalyse ir plinta proksimaliai. Ultragarsiniu plaučių tyrimu galima nustatyti tam tikro ploto ir visą plautį apimančio oringumo sumažèjimą, esant ūmiam respiracinio distreso sindromui $[5,6]$. Būdingi alveolių pažeidimai ir plaučių edema, intersticiumo sustorèjimas. Pradžioje kompiuterinès tomografijos vaizduose matomi ,matinio stiklo“ pakitimai, vẻliau išryškèja didesnès konsolidacijos zonos. Patologini COVID - 19 pneumonijos 


\section{4}

progresavimui būdingą vaizdą puikiai parodo plaučių ultragarsinis tyrimas (1 pav.) [4].

Normaliai ultragarsinio tyrimo metu plautyje matomos A linijos. Tai horizontalios linijos, pleuros atspindys oringame plautyje. Ligai progresuojant, ultragarsiniame plaučių tyrime išryškejja B1 linijos, kurios rodo intersticinio audinio sustorejimą ir uždegimo paveiktą plaučių audinį. Kuo sunkesnè ligos forma, tuo didesnis B linijų skaičius, didejjant konsolidacijos (C) zonų kiekiui ir dydžiui [7]. Susiliejusios B linijos (B2) rodo sunkų plaučių pažeidimą, vadinamą baltaisiais plaučiais. Didesniam ultragarsinio tyrimo patikimumui galima ištirti daugiau plaučių zonų, tačiau tam reikia patyrusio specialisto ir daugiau laiko. Šešių zonų ištyrimas duotų patikimą tyrimo išvadą [4].

Vertinimui dinamikoje kasdien gali būti apskaičiuojamas plaučių ultragarso balas. Skenuojami trys skirtingi krūtinès ląstos plotai: priekinis, šoninis ir užpakalinis. Po to išskiriami kievieno jų apatiniai ir viršutiniai segmentai. Gaunami 6 segmentai. Taškų vertinimo sistema naudojama vertinant pažeidimus kiekviename plote: A linijos -0 taškų, B1 linijos -1 taškas, B2 -2 taškai, $\mathrm{C}-3$ taškai. Sudejjus visų zonų taškus, sveiko žmogaus UG balas lygus 0 , o sunkiausio plaučių pažeidimo atveju gaunami 36 balai [8]. Šie balai gali būti naudojami vertinti pažeistų plaučių būklès gerējimą ar blogèjimą. Didèjantis balas parodo plaučių oringumo mažèjimą, o jo mažèjimas rodo gerèjančią plaučių būklę, didèjantị oringumą [9].

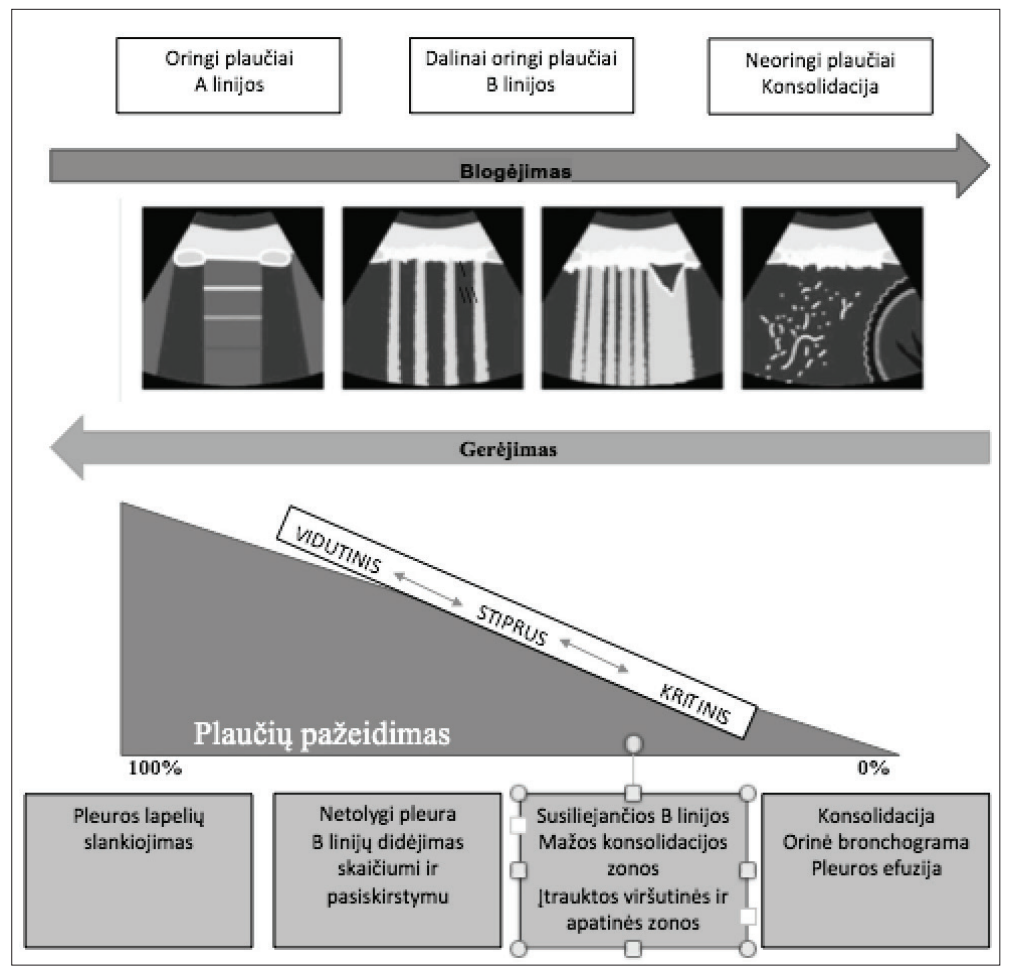

1 pav. Ultragarsinio tyrimo charakteristikos, esant vidutiniam, stipriam ir kritiniam plaučių pažeidimui
Nustatyta, kad krūtinès ląstos rentgenogramos galimybè identifikuoti bakterinę ar virusinę infekciją siekia 60 procentų.Ultragarsinio tyrimo jautrumas šiuo atžvilgiu yra didesnis ir siekia net iki 80 procentų [10]. Kitas plaučių ultragarsinio tyrimo privalumas yra tas, kad vertinant plaučių pažeidimo dydị, ši tyrimą galima dažnai atlikti prie paciento lovos, sumažinant pacientui kenksmingų rentgenologinių ir kompiuterinès tomografijos tyrimų atlikimą [11].

\section{Išvados}

1. Ultragarsinis tyrimas yra naudingas diagnostikos metodas apibūdinti COVID-19 liga sergančių pacientų plaučiu pažeidimo lygį.

2. Vertinant dinamikoje atsirandančias A, B1, B2, C struktūras, nustatomas plaučių pažeidimo lygis.

3. Naudojant plaučių ultragarso balą, galima vertinti kvèpavimo nepakankamumo, plaučių pažeidimo lygị dinamikoje.

4. Ultragarsinis tyrimas pranašesnis dèl mažiau žalingo poveikio pacientams nei krūtinès ląstos rentgenograma ar kompiuterinès tomografijos tyrimas, nes atliekant tyrimą nenaudojama žalinga spinduliuotè.

\section{Literatūra}

1. World Health Organization. Coronavirus disease 2019 (COVID-19): situation report, 52. 2020.

2. Winkler M, Touw H, van de Ven P, et al. Diagnostic accuracy of chest radiograph, and when concomitantly studied lung ultrasound, in critically ill patients with respiratory symptoms: a systematic review and meta-analysis. Critical Care Medicine 2018;46:e707-14.

https://doi.org/10.1097/CCM.0000000000003129

3. Huang Y, Wang S, Liu Y, et al. A preliminary study on the ultrasonic manifestations of peripulmonary lesions of non-critical novel coronavirus pneumonia (COVID-19). SSRN 2020. https://doi.org/10.2139/ssrn.3544750

4. Smith MJ, Hayward SA, Innes SM, Miller ASC. Point-of-care lung ultrasound in patients with COVID-19 - a narrative review. Anaesthesia 2020;74(8):1096-1104.

https://doi.org/10.1111/anae.15082

5.Chiumello D, Mongodi S, Algieri I, et al. Assessment of lung aeration and recruitment by CT scan and ultrasound in acute respiratory distress syndrome patients. Crit Care Med 
2018;46:1761- 8 .

https://doi.org/10.1097/CCM.0000000000003340

6. Mongodi S, Bouhemad B, Orlando A, et al. Modified lung ultrasound score for assessing and monitoring pulmonary aeration. Ultraschall Med 2017;38:530-7. https://doi.org/10.1055/s-0042-120260

7. Peng Q, Wang X, Zhang L. Findings of lung ultrasonography of novel corona virus pneumonia during the 2019-2020 epidemic. Intensive Care Medicine 2020. https://doi.org/10.1007/s00134-020-05996-6

8. Vetrugno L, Bove T, Orso D, Barbariol D. Our Italian experence using lung ultrasound for identification, grading and serial follow-up of severity of lung involvement for management of patient with COVID-19. Echocardiography 2020;37(4): 625-627. https://doi.org/10.1111/echo.14664

9. Bouhemad B, Mongodi S, Via G, Rouquette I. Ultrasound for "Lung Monitoring" of ventilation patients. Anesthesiology 2015;122:437- 447. https://doi.org/10.1097/ALN.0000000000000558

10. Berce V, Tomazin M, Gorenjak M, Berce T, Lovrenčič B. The usefulness of lung ultrasound for the aetiological diagnosis of community-acquired pneumonia in children. Sci Rep 2019;9(1):17957.

https://doi.org/10.1038/s41598-019-54499-y

11. Brogi E, Bignami E, Sidoti A, et al. Could the use of bedside lung ultrasound reduce the number of chest $\mathrm{x}$-rays in the intensive care unit? Cardiovasc Ultrasound 2017;15-23.

https://doi.org/10.1186/s12947-017-0113-8

\section{ASPECTS AND CLINICAL BENEFITS OF LUNG ULTRASOUND EVALUATIONS IN COVID 19 PATIENTS \\ V. Galdikaitė, M. Pinchasov}

Keywords: COVID-19, SARS-CoV-2, coronavirus, ultrasound, sonography, lungs, chest.

Summary

The COVID 19 pandemic has put a significant pressure on the healthcare system. Ultrasound examination of the lungs for the diagnosis of lung damage during the disease showed it to havea great clinical value. Ultrasound examination of healthy lungs shows A lines showing healthy aerated lungs. As COVID disease progresses, B1 lines appear, indicating thickening of the interstitial tissue and lung tissue inflammation. In more severe cases of the disease, the B lines merge, their number increases, so-called "white lungs"(B2 lines). In the case of a severe form of the disease, so-called consolidation zones appear. By evaluating these features in 6 different segments, it is possible to calculate an ultrasound score, which is useful in assessing lung damage in dynamics, the higher the number, the lower the lung airiness, and vice versa. The advantage of pulmonary ultrasound is that it can be performed as often as needed because it is not as harmful to the patient as an X-ray or computer tomography scan because of its radiation.

Correspondence to: vilma.galdikaite@gmail.com

Gauta 2021-05-18 